\title{
THE DESTRUCTIVE EFFECT OF TRACES OF ZINC SALTS ON COMPLEMENT
}

\author{
BY \\ A. E. WILKINSON \\ From the Medical Research Council V.D. Reference Laboratory
}

(RECEIVED FOR PUBLICATION JUNE 29, 1950)

Price (1949) has advocated a method of complement titration in which graded complement dilutions are exposed to the action of $(a)$ saline, $(b)$ normal serum and antigen, and $(c)$ normal serum under the conditions used in the actual test. During the complement titration for a gonococcal complement fixation test, the highest dilution of complement giving sparkling lysis in $(a)$ was unusually low, whereas (b) and (c) gave average titres for the complement being used. This discrepancy was thought to merit investigation.

The complement was the pooled serum of about 70 large male guinea-pigs, preserved by Richardson's (1941) method. The haemolytic immune body was also part of a large pool. As both these reagents had been in general use in the laboratory and no previous difficulties had been encountered, it was thought they could be exonerated. The saline was freshly prepared from A.R. sodium chloride ; on testing for zinc with sodium di-ethyl-dithiocarbamate, as recommended by Mackie and McCartney (1945), a definite turbidity was produced.

Parallel complement titrations were then put up with the same complement. amboceptor, and sheep cells for each, but using saline prepared from the $\mathrm{NaCl}$ containing zinc and from a batch from another maker which gave no turbidity with the zinc reagent. The total volume of the reagents was kept constant by varying the volume of saline in each mixture. The highest dilutions of complement giving complete lysis were:

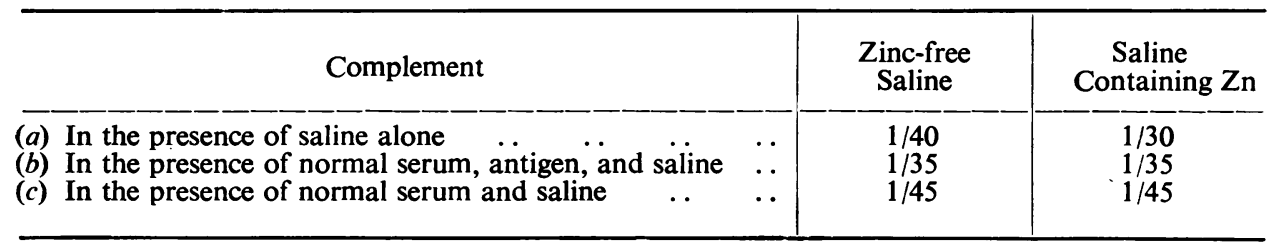

Thus the same pattern of results was reproduced experimentally.

The following practical aspects of the destructive effect of zinc on complement, which might affect complement fixation tests, were investigated. The minimum inhibitory dose of zinc ; the effect of time and temperature of incubation ; the neutralization of the destructive effect by serum ; the effect of zinc-containing $\mathrm{NaCl}$ on the preservation of complement by Richardson's method; the estimation of traces of zinc in sodium chloride. 


\section{Technique and Reagents}

The same basic technique was used throughout these experiments. The unit volume used was $0.11 \mathrm{ml}$., being measured by a teated Pasteur pipette calibrated to deliver this volume. The reagents were made up to a total of three volumes with zinc-free saline, incubated in a $37^{\circ} \mathrm{C}$. water bath for one hour unless otherwise stated, and one volume of a fresh $2 \frac{1}{2} \%$ sheep cell suspension, standardized by a haematocrit method (Price and Wilkinson, 1947) and sensitized with 5 M.H.D. rabbit anti-sheep cell haemolysin added to each tube. After 30 minutes' further incubation at $37^{\circ} \mathrm{C}$., the tubes were centrifuged and the degree of lysis estimated by comparison with freshly prepared standards ranging from $0-100 \%$ lysis in increments of $10 \%$. For these comparisons $75 \times 5 \mathrm{~mm}$. tubes of uniform bore were used. All experiments were put up in duplicate.

Complement.-This was preserved by Richardson's method, and each batch was used within a month of preparation.

Stock Zinc Solution.-This was prepared from A.R. zinc acetate and contained $1 \mathrm{mg}$. $\mathrm{Zn} / \mathrm{ml}$. The acetate was chosen, as Wright and MacCallum (1922) have shown that this ion was the least destructive of complement of any they studied.

\section{Results}

Minimum Inhibitory Amount of Zinc.-One volume of complement 1 in 80, 1 volume of saline containing $0.01-1.0 \mathrm{mg}$. $\mathrm{Zn} / 100 \mathrm{ml}$, and 1 volume of zinc-free saline were incubated at $37^{\circ} \mathrm{C}$. for an hour. One volume of sensitized cells was added and the degree of lysis estimated after a further 30 minutes at $37^{\circ} \mathrm{C}$. The results are shown in Table I.

\section{TABLE I}

DETERMINATION OF THE MINIMUM INHIBITORY LeVEL OF ZiNC

\begin{tabular}{|c|c|c|c|c|c|c|c|}
\hline \multicolumn{7}{|c|}{ Zinc Content of Saline (mg./100 ml.) } & \multirow{2}{*}{$\begin{array}{c}\text { Haemolysis (\%) } \\
0 \\
22.5 \\
67.5 \\
80 \\
85 \\
87.5 \\
92.5 \\
95\end{array}$} \\
\hline $\begin{array}{l}1.0 \\
0.5 \\
0.25 \\
0.10 \\
0.075 \\
0.05 \\
0.025 \\
0.01\end{array}$ & $\begin{array}{l}\cdots \\
\cdots \\
\cdots \\
\cdots \\
\cdots \\
\cdots\end{array}$ & $\begin{array}{l}\cdots \\
\cdots \\
\cdots \\
\cdots \\
\cdots \\
\cdots \\
\cdots\end{array}$ & $\begin{array}{l}\cdots \\
\ldots \\
\ldots \\
\ldots \\
\ldots \\
\ldots \\
\ldots\end{array}$ & 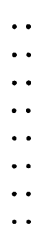 & 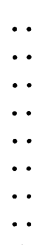 & $\begin{array}{l}\ldots \\
\ldots \\
\ldots \\
\ldots \\
\ldots \\
\ldots \\
\ldots\end{array}$ & \\
\hline \multicolumn{3}{|c|}{ Control (no zinc) } & .. & . & $\cdots$ & . & 95 \\
\hline
\end{tabular}

The figures (Table I) show that complement destruction first becomes appreciable with amounts of zinc between 0.05 and $0.1 \mathrm{mg}$. $/ 100 \mathrm{ml}$. corresponding to $0.0014-0.0028 \%$ $\mathrm{Zn}$ in $\mathrm{NaCl}$. Mackie and McCartney (1945) quote unpublished work by Richardson, who found the maximum permissible amount of zinc in $\mathrm{NaCl}$ to be $0.0022 \%$. Lührs (1939) showed that $1.0-2.0 \mathrm{ml}$. of a $1 / 10,000$ solution of colloidal zinc oxide caused complete inhibition of lysis by $1 \mathrm{ml}$. of $2 \%$ guinea-pig serum.

The minimum inhibitory dose of zinc varies with the amount of complement in the reaction mixture. In the experiment described above, the dose of complement $(1 / 80)$ was just insufficient to give complete lysis of the control. Using the same complement diluted 1 in 50 , the minimum inhibitory dose of zinc was found to be between 1 volume of $0.25 \mathrm{mg}$. $\mathrm{Zn} / 100 \mathrm{ml}$. and $0.5 \mathrm{mg}$. $\mathrm{Zn} / 100 \mathrm{ml}$. saline. 
Effect of Duration and Temperature of Incubation.- - In a similar experiment 1 volume of complement diluted 1 in 80 was exposed to the action of 1 volume of saline containing $0.2 \mathrm{mg}$. $\mathrm{Zn} / 100 \mathrm{ml}$. for periods of $0-120$ minutes at $37^{\circ} \mathrm{C}$. before sensitized cells were added. After one hour enough complement remained in the zinc-containing tubes to give $31 \%$ lysis, while the control (zinc-free) tubes showed $64 \%$ lysis. After two hours the respective figures were $2.5 \%$ and $31 \%$.

The temperature of incubation was also of importance. Destruction was slight at $6^{\circ} \mathrm{C}$. and $18^{\circ} \mathrm{C}$, , but considerable at $37^{\circ} \mathrm{C}$.

Neutralization of Destructive Effect by Serum.-Two parallel sets of tubes were put up containing 1 volume of complement diluted 1 in 80 and 1 volume of pooled human serum inactivated at $56^{\circ} \mathrm{C}$. for 30 minutes in dilutions from 1 in 10 to 1 in 300 in saline. To one set of tubes was added 1 volume of saline containing $0.5 \mathrm{mg}$. $\mathrm{Zn} / 100 \mathrm{ml}$. and to the other set 1 volume of zinc-free saline. Both sets were incubated at $37^{\circ} \mathrm{C}$. for one hour, and the amount of lysis estimated after a further 30 minutes at $37^{\circ} \mathrm{C}$. after the addition of sensitized cells. These results are shown in Table II.

TABLE II

The Protective Action of Serum on the Inactivation of Complement by Zinc

\begin{tabular}{|c|c|c|c|c|c|c|c|c|}
\hline & \multirow{2}{*}{\multicolumn{4}{|c|}{ Dilution of Serum }} & & \multicolumn{2}{|c|}{ Lysis $(\%)$} \\
\hline & & & & & & & Zinc & Control (No Zinc) \\
\hline $\begin{array}{l}1 \text { in } 10 \\
1 \text { in } 20 \\
1 \text { in } 40 \\
1 \text { in } 80 \\
1 \text { in } 120 \\
1 \text { in } 160 \\
1 \text { in } 200 \\
1 \text { in } 250 \\
1 \text { in } 300\end{array}$ & $\begin{array}{l}\ldots \\
\ldots \\
\ldots \\
\ldots \\
\ldots \\
\ldots \\
\ldots \\
\ldots\end{array}$ & $\begin{array}{l}\ldots \\
\ldots \\
\ldots \\
\ldots \\
\ldots \\
\ldots \\
\ldots \\
\ldots\end{array}$ & $\begin{array}{l}\ldots \\
\ldots \\
\ldots \\
\ldots \\
\ldots \\
\ldots \\
\ldots \\
\ldots\end{array}$ & $\begin{array}{l}\ldots \\
\ldots \\
\ldots \\
\ldots \\
\cdots \\
\ldots \\
\ldots\end{array}$ & $\begin{array}{l}\cdots \\
\cdots \\
\cdots \\
\cdots \\
\cdots \\
\cdots \\
\cdots \\
\cdots\end{array}$ & $\begin{array}{l}\ldots \\
\cdots \\
\cdots \\
\cdots \\
\cdots \\
\ldots \\
\cdots \\
\ldots\end{array}$ & $\begin{array}{r}85 \\
70 \\
30 \\
7 \\
0 \\
0 \\
0 \\
0 \\
0\end{array}$ & $\begin{array}{l}85 \\
95 \\
92.5 \\
85 \\
72.5 \\
70 \\
57.5 \\
60 \\
55\end{array}$ \\
\hline Control & . & & & & & & & \\
\hline
\end{tabular}

These figures show that the presence of serum in the reaction mixture affords considerable protection to complement in the presence of relatively large amounts of zinc, in this instance about six times the minimum inhibitory dose.

The means by which serum exerts this protective action is not clear, and it is hoped to investigate this question further. It raises one point of practical importance. If a complement titration is carried out using saline contaminated with zinc salts and the dose of complement is estimated from the highest dilution of complement giving complete lysis in the presence of saline alone, the value arrived at will be too large, since in the test proper the tubes will contain sufficient serum to exert a protective effect. This excess of complement will lower the sensitivity of the test. If complement doses are gauged from a consideration of complement dilutions exposed under the conditions of the test to the presence of $(a)$ normal serum, and $(b)$ normal serum plus antigen, as advocated by Price (1949), this underestimate of complement activity is avoided.

Effect of Zinc-containing $\mathbf{N a C l}$ on Preservation.-The reagents used in the Richardson method for preserving complement are dissolved in saturated aqueous $\mathrm{NaCl}$. If this contained zinc, the concentrated solution might be expected to introduce relatively large amounts of zinc into the complement, although the serum proteins might offset the destructive effect. Portions of the same pool of guinea-pig serum were preserved with 
reagents dissolved in $(a)$ zinc-free saline, and $(b)$ saline from $\mathrm{NaCl}$ containing $0.004 \% \mathrm{Zn}$. The lytic effect of dilutions of both specimens of complement against the same batch of sensitized cells was determined after incubation at $37^{\circ} \mathrm{C}$. for one hour before the addition of cells. The amount of lysis produced by the complement preserved with the zinccontaining salt was slightly less than the control, but the difference was not considered significant.

The Estimation of Traces of Zinc in NaCl.-The method described by Atkins (1935), which will detect as little as 0.06 parts per million of zinc in water, was used. A series of standard solutions containing from 1.0 to $0.01 \mathrm{mg}$. $\mathrm{Zn}$ in $50 \mathrm{ml}$. volumes of distilled water was prepared in 6 in. $\times 1$ in. tubes of uniform bore. A blank containing $50 \mathrm{ml}$. of the distilled water used for preparing the solutions was included. The unknown consists of $50 \mathrm{ml}$. of a $1 \%$ solution of the $\mathrm{NaCl}$ under test. To each tube was added $5.0 \mathrm{ml}$. of a freshly prepared $0.1 \%$ aqueous solution of sodium di-ethyl-dithiocarbamate (B.D.H. reagent for delicate analysis). The contents of the tubes were mixed, allowed to stand for 30 minutes, and any turbidity produced compared with the standards. The turbidity produced by zinc is clarified by the addition of $0.880 \mathrm{NH}_{4} \mathrm{OH}$, whereas that produced by copper is not. Copper and iron salts produce a brownish opalescence which may interfere with the estimation.

Eight batches of $\mathrm{NaCl}$ of A.R. purity were examined. In six of these no zinc could be detected. In one, a trace was present, well below $0.002 \%$, while the remaining specimen was found to contain $0.004 \% \mathrm{Zn}$.

\section{Summary}

The presence of zinc in $\mathrm{NaCl}$ in amounts greater than $0.002 \%$ has been found to reduce the haemolytic activity of complement.

The effect of duration and temperature of incubation on this action of zinc has been examined.

The presence of serum has been found to lessen the destructive effect of zinc.

A simple method of estimating traces of zinc in $\mathrm{NaCl}$ is suggested.

My thanks are due to Dr. I. N. Orpwood Price, Director of the Medical Research Council V.D. Reference Laboratory, for his constant encouragement and advice during the course of this investigation, part of which was carried out during the tenure of an Insole Scholarship awarded by the British Medical Association.

\section{REFERENCES}

Atkins, W. R. G. (1935). Analyst, 60, 400.

Lührs, E. (1939). Z. ImmunForsch., 95, 70.

Mackie, T. J., and McCartney, J. E. (1945). Handbook of Practical Bacteriology, 7th ed., p. 671. Edinburgh.

Price, I. N. O. (1949). Brit. J. vener. Dis., 25, 157.

- and Wilkinson, A. E. (1947). Ibid., 23, 124.

Richardson, G. M. (1941). Lancet, 2, 696.

Wright, H. D., and MacCallum, P. (1922). J. Path. Bact., 25, 316. 